\title{
S1PR5 wt Allele
}

National Cancer Institute

\section{Source}

National Cancer Institute. S1PR5 wt Allele. NCI Thesaurus. Code C104783.

Human S1PR5 wild-type allele is located in the vicinity of 19p13.2 and is approximately 11

$\mathrm{kb}$ in length. This allele, which encodes sphingosine 1-phosphate receptor 5 protein, is involved in the regulation of cell proliferation, apoptosis, motility, and neurite retraction. 